\title{
Modelling strategy and net employment effects of renewable energy and energy efficiency: A meta-regression
}

\author{
S. Stavropoulos ${ }^{\text {a, }}$, M.J. Burger ${ }^{\text {b,c }}$ \\ ${ }^{a}$ Department of Applied Economics, Tinbergen Institute and Researcher at the Erasmus Happiness Economics Research Organization, Erasmus University, Rotterdam, the \\ Netherlands \\ ${ }^{\mathrm{b}}$ Department of Applied Economics, Erasmus University, Rotterdam, the Netherlands \\ ${ }^{\mathrm{c}}$ Tinbergen Institute and academic Director at the Erasmus Happiness Economics Research Organization, P.O. Box 1738, 3000, DR Rotterdam, the Netherlands
}

\section{A R T I C L E I N F O}

\section{Keywords:}

Renewable energy

Net employment

Meta-analysis

Circular economy

\begin{abstract}
A B S T R A C T
By conducting a meta-analysis of the empirical literature on the net employment effects of renewable energy, we explore the extent to which the reported net employment effects are driven by the applied methodology. We find that the reported conclusions on net employment effects are to a large extent driven by the methodology that is applied, where computable general equilibrium (CGE) and I/O methods that include induced effects and studies that consider only the near future in their study period (up to 2020) are generally less optimistic about net employment creation in the wake of the energy transition. In addition, we found that policy reports have a greater tendency to report a positive net employment effect than academic studies.
\end{abstract}

\section{Introduction}

Over the past few years, development of the circular economy (CE) has received increasing attention. The circularity of economic processes means that fewer unusable final components, products and energy remain at the end of production and consumption cycles, which minimizes both waste and pollution by saving on production inputs such as materials and energy (Lovins and Michael, 2014); (Lacy and Rutqvist, 2016). The Ellen MacArthur Foundation has distinguished four core strategies that can be used to move from a linear economy to a CE; these strategies are discussed throughout the whole CE literature (Van Oort et al., 2018) and are inherently linked to the R-frameworks or the 'how-to' frameworks of the CE (Kirchherr et al., 2017); (Burger et al., 2019). First, the prioritization of regenerative resources should ensure that renewable and reusable resources are efficiently utilized as energy and materials. Second, resource preservation through maintenance, repair and upgrades should maximize the lifetimes of resources. Third, the utilization of waste streams as secondary resources should result in the useful application of materials. Fourth, the sharing economy should stimulate more intensive product use and reuse.

Existing CE research and policy reports generally claim that it will result in economic prosperity, jobs, and improved well-being. For example, a recent report by WRAP (UK) (Morgan and Mitchell, 2015a,
Morgan and Mitchell, 2015b) indicated that the CE could create 3 million extra jobs and reduce unemployment by 520,000 in EU member states by 2030 (also considering job offsets in other sectors). However, these conclusions are drawn under the assumption of significantly increasing recycling rates (by $34 \%$ ) with substantial advancement in remanufacturing and servitization activities. In a more modest scenario outlined by WRAP, the number of jobs would increase by only 250,000 in the EU member states, reducing unemployment by 64,000 by 2030 (Morgan and Mitchell, 2015a, Morgan and Mitchell, 2015b). Jobs may be replaced, or job creation may be reduced by mechanization or automatization, which will make some occupations obsolete in the future (Frey and Osborne, 2017). Overall, the potential economic effects of the rise of the $\mathrm{CE}$ as well as estimates on how many jobs will be lost are rather unclear.

The CE may have both a positive and negative effect on employment creation; this is not usually addressed in gross circular employment estimations. On the one hand, the CE creates new jobs in the energy, production, and services industries. On the other hand, the CE can also negatively impact the economy in two distinct ways. First, the CE can crowd out or substitute traditional sectors. For example, the rise of wind and solar energy will make coal fired power plants redundant. Second, additional consumption of circular products and services can reduce the budget for other expenditures, resulting in job losses in the targeted

\footnotetext{
* Corresponding author. Department of Applied Economics, Tinbergen Institute and Researcher at the Erasmus Happiness Economics Research Organization, Erasmus University, Rotterdam, the Netherlands.

E-mail addresses: stavropoulos@ese.eur.nl (S. Stavropoulos), mburger@ese.eur.nl (M.J. Burger).
} 
sectors. Both positive and negative impacts are multiplied and distributed through the economic system: increased employment increases expenditures for consumption (i.e., induced employment) and creates jobs in the respective sectors (as well as increases taxes). The negative effects of the CE work in a similar fashion. However, the potential job losses due to an increasing number of green jobs and enhanced technology are not considered in the gross employment estimates provided.

To obtain information on the net effects, one has to employ a model of the total (regional or national) economy. In economics, this is usually done through computational equilibrium modelling (CGE) or treatment effect (also known as impact analysis) models. In a recent report by Cambridge Econometrics, Trinomics, and ICF (Cambridge Econometrics, Trinomics, 2018), the institutions forecasted that the $C E$ would have a positive effect on employment $(0.3 \%)$ in the EU. However, while some sectors (e.g., repair, recycling and waste management, and utilities) are expected to experience employment growth due to development of the $\mathrm{CE}$, for other sectors (e.g., construction, consumer electronics, and motor vehicle construction), a loss in employment is expected. Likewise, some countries seem to profit more (e.g., Austria, Malta, the Netherlands, and Spain) than others (e.g., Croatia, Finland, Hungary, and Slovakia) from the rise of the CE. At the same time, an important limitation of the model used in the Cambridge Econometrics, Trinomics, and ICF report is that their results are largely contingent on the market uptake of circular activities, and no other comparison studies are available.

Although there is only limited information on the net employment effects of the $\mathrm{CE}$ as a whole and on recycling, refurbishment and other circular economy activities, there are now several studies on the net employment effects of renewable energy and energy efficiency. Here, we define renewable energy as "energy that is collected from renewable resources, which are naturally replenished on a human timescale, such as sunlight, wind, rain, tides, waves, and geothermal heat' (Ellabban et al., 2014). Although renewable energy can replace employment in traditional energy sectors such as coal and gas, renewable energy generally is more labour-intensive for producing electricity than conventional fossil fuelled power plants. This is particularly true for solar and hydro power, while for wind power, biofuel and biomass, the net employment effects are typically smaller (Meyer and Sommer, 2014). Part of the renewable energy sector's labour intensity is driven by the belief that it is more domestically produced than fossil fuelled energy. Energy efficiency (e.g., thermal insulation of buildings) is also part of CE development since it reduces energy use. Energy efficiency measures are expected to have a positive effect on net employment effects because of their positive income effect: people can buy other goods and services because they spend less money on energy (Hergovich and Paprsek, 2015).

As shown in the recent research syntheses of UKERC (Blyth, W., et al., 2014) and Meyer and Sommer (2014), studies that assess the net employment effects of renewable energy and energy efficiency generally report a positive net employment effect of such an energy transition. At the same time, not all studies report solely net positive effects and renewable energy proponents and opponents can easily choose any study they like to support their point of view, while at the same time, the underlying reasons for these differences in outcomes remain unclear.

Although differences across studies can be attributed to their context (time frame, country, and elements of renewable energy), another possible reason for these differences is the methodology that is applied. Studies have used a variety of methods (Computable general equilibrium (CGE) modelling framework, input-output (I/O) methods and survey-based analytical methods) and these methods differ in the extent they can account for induced effects in their estimations including decreasing investments in fossil energy plants, competition for capital, and changes in electricity prices, labour wages, and household income. However, studies that include a wide range of induced effects (using a CGE modelling framework) are thin on the ground since they are computationally more complex and require employment data for all sectors in the economy (Mu et al., 2018), which is not always available.
From a methodological point of view, the inclusion of induced effects is, however, warranted and omitting them can result in an overestimation or underestimation of the net employment effect. If this is the case, this is important to know because it can potentially lead to wrong conclusions whether shifting to renewable energy has a positive effect on the overall number of jobs in the economy, herewith wrongly informing the debate on the energy transition.

Building on the studies of UKERC (Blyth, W., et al., 2014) and Meyer and Sommer (2014), the main purpose of this paper is not only to summarize whether going from fossil energy to renewable energy creates net employment effects but also why studies differ in terms of the reported effects. In particular, we explore in this meta-analytic study the extent to which the reported net employment effects are driven by the applied methodology. Our contribution to the literature is twofold. First, we are to the best of our knowledge the first paper that systematically examines the influence of estimation technique and included effects on reported net employment effects of renewable energy. Second, this study contributes to the policy debate by informing policymakers and politicians about the dangers involved drawing conclusions based on a single study and not critically assessing the methodology behind the studies.

\section{Problem: methodology and reported net employment effects}

How can methodology affect results of net employment estimations? There are currently three main methods used to examine the net employment effects of renewable energy and energy efficiency measures: CGE methods, I/O methods, and survey-based analytical methods. A detailed description of the different methods can be found in Lambert and Silva (2012).

As pointed out by Mu et al. (2018), the three methods differ in their capability to estimate direct, indirect, and induced effects of renewable energy and a change in energy efficiency. Here, the direct employment effects are the jobs created due to the increased capacity of renewable energy, while indirect employment effects are related to the jobs that are created in the industries that support the expansion of the renewable energy sector. The overall impact of both the direct and indirect employment effects on net employment is considered to be positive. In contrast, the induced effects can have either a positive or negative effect or, in some cases, a straightforward negative effect on overall employment. Induced effects can range from decreasing investments in fossil energy plants and changes in electricity prices to competition for capital, changes in labour wages, and changes in household income (Mu et al., 2018). In particular, the disappearance of conventional energy sources and competition for capital are expected to decrease net employment in the wake of the renewable energy transition through price increases.

While all methods (CGE, I/O, and analytical) are capable of including direct and indirect effects, they vary in the degree to which they can include induced effects. CGE methods are capable of including most kinds of induced effects, while I/O methods can only address investment decreases in traditional energy sources and changes in household income, particularly because it is often assumed in these models that the supply of capital and labor is infinite. ${ }^{1}$ Analytical methods are not able to simulate any induced effects (Mu et al., 2018), but are part and parcel of the net employment literature (Schut, E., et al., 2016) (Kirchherr et al., 2017); that has examined the rise of the renewable energy sector, particularly in influential policy reports drawn up by government organizations and charitable foundations. One reason for using this method is that this method is less computationally complex and has less data requirements compared than, for example, CGE.

However, ignoring, even in part, the induced effects may make the energy transition's employment estimates too positive. For example, if the shift to renewable energy will make the generation of electricity more costly and investment in renewable energy can make capital

\footnotetext{
${ }^{1}$ See Mu et al. (2018) for a more detailed discussion of this.
} 
scarcer in other parts of the economy. As pointed out by Lesser (2010) such induced effects can incur serious job losses and should therefore be taken into any estimation of net employment effects. Because of measurement difficulties, the literature has, however, paid less attention to induced impacts.

\section{A meta-regression on the reported net employment effects and methodology}

To examine the effect on methodology on reported net employment effects, we acquired a systematic and representative set of journal articles, from JSTOR, Science Direct, ISI Web of Science, and Google Scholar using the following set of keywords: 'renewable energy', 'net employment' or 'net jobs', and 'green growth'. We gathered academic studies and policy reports containing these keywords. Using the snowballing technique (Johnson, 2014), we carefully scanned the references of all the journal articles, book chapters and agency reports that were obtained in our initial search to find other related studies. Subsequently, we reviewed all of the articles and included only those estimates that (a) reported net employment effects and (b) included sufficient information regarding their study design and empirical strategy. Several studies were excluded from our meta-analysis. First, as in this study, we only look at net employment effects; all studies reporting gross employment in the renewable energy sector were excluded. Second, studies that - in addition to renewable energy - also examined other circular sectors (such as recycling or repair) were excluded. Third, we excluded studies and reports written in a language other than English. In total, 30 journal articles and reports fulfilled our criteria to a sufficient degree. The majority of the studies we examined were published after 2000; only 4 were published before 2000, indicating that the relationship between net employment effects and renewable energy has received particular attention in recent decades.

Table 1 provides information on the studies we included in our metaanalysis. $^{2}$ Based on the reported effect sizes of each study, we categorized the studies into three categories: positive, mixed or negative net employment effects. A study receives the label 'positive net employment effects' if all presented models in the study report a positive net employment effect of renewable energy. A study receives the label 'negative net employment effects' if all presented models in the study report a negative net employment effect of renewable energy. A study receives the label 'mixed net employment effects' if the presented models in the study report a combination of negative and positive net employment effects of renewable energy. Hence, in our estimations, we predominantly focuses on the sign and not the magnitude of the net employment effects. This is done because (1) the focus of the study is on the effect of methodology on conclusions regarding net employment effects of renewable energy and (2) countries differ in terms of labor market size, which makes it difficult to compare actual effect sizes, especially given that for many countries only one study has been conducted. However, to get an idea of the size of the effects, we report the effect sizes obtained in the studies in the table below, where for studies with more than one estimation the upper (maximum) and lower (bound) are reported. The average effect size range from +24000000 to -2250000 .

In terms of which renewable energy sectors are scrutinized (Table 2), most studies examine the net employment effects of the renewable energy sector as a whole, while some focus on specific sectors, such as wind energy, biofuels and energy efficiency. In terms of the methodology applied, 18 studies used an I/O analysis, 7 studies used CGE analysis, and 5 studies used analytical methods. Of these, 11 examined only the

\footnotetext{
${ }^{2}$ As a rule of thumb, 10 studies are considered enough for a meta-analysis (Tanner-Smith and Tipton, 2014). In this study, we exceed this number and argue that the number of studies included in our paper is more than enough for conducting a meta-analysis.
}

direct effects of net employment on RES and 19 studied the direct, indirect and induced effects. Geographically, studies were conducted on the United States (9 studies) and Germany (8 studies). We found 7 studies that covered other countries, and 6 studies covered a group of countries other than Germany and the United States. The majority of the studies were published in peer-reviewed academic journals (20 studies), and 10 studies were published as reports from consultancies, charitable organizations and/or governments. Most studies focus on the near future, as evidenced by the fact that studies that examine net employment effects up to 2020 are more common than studies that examine net employment effects in the more distant future.

Table 2 also shows the findings by the applied methodology and study focus. Of the 30 studies included in our literature review, 22 reported only positive net employment effects, while 8 reported mixed positive and negative effects or negative net employment effects. The studies using analytical methods only focused on the direct and indirect effects, and policy reports have a greater tendency to report positive effects.

\section{Meta-regression}

\subsection{Meta-regression model}

Due to the nature of the dependent variable, we use a linear probability model, which has been used to estimate dichotomous choice models. This model works as a linear regression model, but differs because the interpretation changes with a binary dependent variable.

$\widehat{P}(y=1 \mid x)=\widehat{y}=\widehat{b}_{0}+\widehat{b}_{1} x_{1}+\ldots+\widehat{b}_{k} x_{k}$

where $\hat{y}$ is the predicted probability of $y=1$ for the given values of $x_{1} \ldots x_{k}$.

The linear probability model has been criticized by some scholars because of heteroscedasticity and the possibility of predicting probability outside the $0-1$ interval. The heteroscedasticity can be fixed by using robust standard errors. Moreover, in our study, the predicted probability lies inside the unit interval, so our main estimate is unbiased and consistent. In our case, the advantage of using a linear probability model over a logit or probit model is that some parameters of importance can be estimated. In particular, our model contains dummy variables that indicate whether the study uses analytical models and whether the study is a peer-reviewed academic study. Since studies that belong to both groups solely report positive net employment effects, logit or probit models are not able to estimate a coefficient of these group dummy variables. This is, however, possible with a linear probability model. For a detailed discussion of the advantages of using the linear probability model over logit or probit models, please refer to Caudill (1988).

\subsection{Meta-regression results}

Table 3 shows estimates of the linear probability model on the probability that a study will only report positive net employment effects. Our full model explains $55 \%$ of the variation in the reported effects. In Model 1, only the modelling strategy is included in our estimation. We find that studies using a survey-based analytical method are more likely to report larger net employment effects. Compared to using CGE models (which can incorporate all kinds of induced effects), using analytical methods increases the probability of reporting a positive effect by $43 \%$. The difference between the CGE and I/O methods is statistically not significant. However, these effects seem to be predominantly driven by the inclusion of induced effects. Model 2 includes the examined effects and a time period. The results indicate that studies considering only direct/indirect effects but excluding induced effects report larger net employment effects. Including the induced effects reduces the probability by almost $50 \%$ that the study will report a positive effect, 
Table 1

Studies included in the meta-analysis.

\begin{tabular}{|c|c|c|c|c|c|c|}
\hline Study & Country & Type & $\begin{array}{l}\text { Effect Size (Lower/Upper) } \\
\text { Bound) }\end{array}$ & $\begin{array}{l}\text { Average Effect } \\
\text { Size }\end{array}$ & $\begin{array}{l}\text { Effect } \\
\text { Found }\end{array}$ & Reference \\
\hline Bach et al. (2002) & GER & Academic & $\begin{array}{l}40000 \\
250000\end{array}$ & 145000 & Positive & Bach et al. (2002) \\
\hline Barrett et al. (2002) & USA & $\begin{array}{l}\text { Policy } \\
\text { Report }\end{array}$ & 1400000 & 1400000 & Positive & Barrett et al. (2002) \\
\hline $\begin{array}{l}\text { Bezdek and Wendling, } \\
\text { (2005) }\end{array}$ & USA & Academic & $\begin{array}{l}48012 \\
319085\end{array}$ & 183548.5 & Positive & Bezdek and Wendling (2005) \\
\hline Blazejczak et al. (2014) & GER & Academic & $\begin{array}{l}2000 \\
263000\end{array}$ & 89333.336 & Positive & Blazejczak et al. (2014) \\
\hline BMU (2006) & GER & $\begin{array}{l}\text { Policy } \\
\text { Report }\end{array}$ & 130000 & 130000 & Positive & Staiß et al. (2006) \\
\hline Böhringer et al. (2013) & GER & Academic & $\begin{array}{l}-1 \\
148600\end{array}$ & 73275 & Mixed & Böhringer et al. (2013) \\
\hline Bouzaher et al. (2015) & TUR & Academic & $\begin{array}{l}20052 \\
26328\end{array}$ & 24113.334 & Positive & Bouzaher et al. (2015) \\
\hline Cai et al. (2011) & $\mathrm{CHN}$ & Academic & $\begin{array}{l}-599000 \\
479000\end{array}$ & 117333.34 & Mixed & Cai et al. (2011) \\
\hline $\begin{array}{l}\text { Chateau and Saint-Martin } \\
\text { (2013) }\end{array}$ & OECD & Academic & $\begin{array}{l}-4000000 \\
-500000\end{array}$ & -2250000 & Negative & Chateau and Saint-Martin (2013) \\
\hline Climate Institute (2009) & AUS & $\begin{array}{l}\text { Policy } \\
\text { Report }\end{array}$ & 26200 & 26200 & Positive & $\begin{array}{l}\text { Clean Energy Jobs and Investment in Regional } \\
\text { Australia (2009) }\end{array}$ \\
\hline EU (2014) & EU & $\begin{array}{l}\text { Policy } \\
\text { Report }\end{array}$ & 2000000 & 2000000 & Positive & Cambridge Econometrics (2014) \\
\hline Henriques et al. (2016) & POR & Academic & $\begin{array}{l}-8402 \\
1041\end{array}$ & -2894.8333 & Negative & Henriques et al. (2016) \\
\hline Heindl and Voigt (2012) & GER & Academic & $\begin{array}{l}-34347 \\
24205\end{array}$ & -5071 & Negative & Heindl and Voigt (2012) \\
\hline Hillebrand et al. (2006) & GER & Academic & $\begin{array}{l}-5000 \\
32300\end{array}$ & 12300 & Mixed & Hillebrand et al. (2006) \\
\hline ILO (2008) & Global & $\begin{array}{l}\text { Policy } \\
\text { Report }\end{array}$ & 24000000 & 24000000 & Positive & UNEP (2008) \\
\hline IDC (2011) & ZA & $\begin{array}{l}\text { Policy } \\
\text { Report }\end{array}$ & $\begin{array}{l}98000 \\
462567\end{array}$ & 280283.5 & Positive & Maia, J et al. (2011) \\
\hline Kammen et al. (2004) & USA & $\begin{array}{l}\text { Policy } \\
\text { Report }\end{array}$ & 240850 & 240850 & Positive & Kammen et al. (2004) \\
\hline Lehr et al. (2012) & GER & Academic & $\begin{array}{l}25000 \\
220000\end{array}$ & 121250 & Positive & Lehr et al. (2012) \\
\hline Lund and Hvelplund (2012) & DEN & Academic & 8000 & 8000 & Positive & Lund and Hvelplund (2012) \\
\hline Markandya et al. (2016) & EU & Academic & 530000 & 530000 & Positive & Markandya et al. (2016) \\
\hline Moreno and López (2008) & ESP & Academic & $\begin{array}{l}10198 \\
10707\end{array}$ & 10472 & Positive & Moreno and López (2008) \\
\hline Moscovitch (1994) & USA & Academic & -101320 & -101320 & Negative & Moscovitch (1994) \\
\hline Neuwahl et al. (2008) & EU & Academic & $\begin{array}{l}-39975 \\
182438\end{array}$ & 50643.625 & Mixed & Neuwahl et al. (2008) \\
\hline Garrett-Peltier (2017) & USA & Academic & $\begin{array}{l}4840 \\
5070\end{array}$ & 4955 & Positive & Garrett-Peltier (2017) \\
\hline PERI (2009) & USA & $\begin{array}{l}\text { Policy } \\
\text { Report }\end{array}$ & 1700000 & 1700000 & Positive & Pollin et al. (2009) \\
\hline Scott et al. (2008) & USA & Academic & $\begin{array}{l}438000 \\
446000\end{array}$ & 442000 & Positive & Scott et al. (2008) \\
\hline Wei et al. (2010) & USA & Academic & $\begin{array}{l}1000000 \\
4000000\end{array}$ & 2500000 & Positive & Wei et al. (2010) \\
\hline Whiteley and Zervos, 1999 & $\mathrm{EU}$ & $\begin{array}{l}\text { Policy } \\
\text { Report }\end{array}$ & $\begin{array}{l}162000 \\
368000\end{array}$ & 265000 & Positive & Whiteley and Zervos (1999) \\
\hline WW Fund for Nature (2001) & USA & $\begin{array}{l}\text { Policy } \\
\text { Report }\end{array}$ & 1314000 & 1314000 & Positive & Bailie et al. (2001) \\
\hline Ziegelmann et al. (2000) & GER & Academic & $\begin{array}{l}31600 \\
160100\end{array}$ & 95850 & Positive & Ziegelmann et al. (2000) \\
\hline
\end{tabular}

controlling for the time frame and methodology. Furthermore, in studies where the period extends beyond 2020, the reported net effects are larger. Studies that examine the more distant future have a $38 \%$ greater probability of reporting a positive net employment effect. These findings hold when controlling for geography and type of study (Models 3 and 4), where we find no differences across countries in terms of the sign of the reported net employment effects. ${ }^{3}$

For Models 3 and 4, our results also support our scepticism regarding the magnitude of effects that non-academic (i.e., non-peer reviewed) papers find. In line with the descriptive statistics, policy reports have a

\footnotetext{
${ }^{3}$ Although this might come across as surprising since nations might differ in their degree of unemployment and, hence, might experience different degrees of net employment creation, countries (and country groups) in our sample are quite homogeneous in that most studies have been conducted in the western world. In this regard, future research should pay more attention the relation between labor market situation and net employment creation.
} 
Table 2

Descriptive statistics of the variables.

\begin{tabular}{llll}
\hline & $\begin{array}{l}\text { Number of } \\
\text { Studies }\end{array}$ & $\begin{array}{l}\text { Positive } \\
(\%)\end{array}$ & $\begin{array}{l}\text { Negative or Mixed } \\
(\%)\end{array}$ \\
\hline CGE & 7 & $4(57 \%)$ & $3(43 \%)$ \\
I/O & 18 & $13(72 \%)$ & $5(27 \%)$ \\
Analytical methods & 5 & $5(100 \%)$ & $0(0 \%)$ \\
Direct and/or Indirect & 11 & $11(100 \%)$ & $0(0 \%)$ \\
$\quad$ Only & 19 & $11(58 \%)$ & $8(42 \%)$ \\
Direct, Indirect and & & & \\
$\quad$ Induced & 18 & $11(61 \%)$ & $7(39 \%)$ \\
Short-Term (up to 2020) & 12 & $11(92 \%)$ & $1(8 \%)$ \\
Long-Term (2020 and & & & \\
$\quad$ beyond) & 4 & $3(75 \%)$ & $1(25 \%)$ \\
Energy Efficiency & 23 & $17(74 \%)$ & $6(26 \%)$ \\
Renewable Energy & 3 & $2(67 \%)$ & $1(33 \%)$ \\
Renewable Energy (Part) & & $5(62 \%)$ & $3(38 \%)$ \\
Germany & 8 & $8(89 \%)$ & $1(11 \%)$ \\
United States & 9 & $5(71 \%)$ & $2(29 \%)$ \\
Other countries & 7 & $4(67 \%)$ & $2(33 \%)$ \\
Country groups & 6 & $12(60 \%)$ & $8(40 \%)$ \\
Academic Study & 20 & $10(100 \%)$ & $0(0 \%)$ \\
Policy Report & 10 & $22(73 \%)$ & $8(27 \%)$ \\
All & 30 & & \\
\hline & & &
\end{tabular}

Table 3

Results of the linear probability model.

\begin{tabular}{|c|c|c|c|c|}
\hline & Model 1 & Model 2 & Model 3 & Model 4 \\
\hline \multicolumn{5}{|l|}{ Modelling Strategy } \\
\hline CGE & Reference & Reference & Reference & Reference \\
\hline $\mathrm{I} / \mathrm{O}$ & $0.15(0.23)$ & $0.27(0.20)$ & $0.06(0.27)$ & $0.20(0.21)$ \\
\hline Analytical methods & $\begin{array}{l}0.43(0.20) \\
*\end{array}$ & $0.16(0.16)$ & $0.24(0.31)$ & $-0.08(0.25)$ \\
\hline \multicolumn{5}{|l|}{ Examined Effects } \\
\hline $\begin{array}{l}\text { Excluding Induced } \\
\text { Effects }\end{array}$ & & Reference & & Reference \\
\hline Including Induced & & $-0.47(0.12)$ & & $-0.51(0.14)$ \\
\hline Effects & & $* *$ & & $* *$ \\
\hline \multicolumn{5}{|l|}{ Period } \\
\hline Short-Term & & Reference & & Reference \\
\hline Long-Term & & $\begin{array}{l}0.38(0.13) \\
* *\end{array}$ & & $0.39(0.14)^{*}$ \\
\hline \multicolumn{5}{|l|}{ Focus } \\
\hline Renewable Energy & & & Reference & Reference \\
\hline $\begin{array}{l}\text { Renewable Energy } \\
\text { (Part) }\end{array}$ & & & $\begin{array}{l}-0.07 \\
(0.30)\end{array}$ & $-0.12(0.22)$ \\
\hline Energy Efficiency & & & $0.21(0.20)$ & $0.06(0.26)$ \\
\hline \multicolumn{5}{|l|}{ Area } \\
\hline United States & & & Reference & Reference \\
\hline Germany & & & $0.02(0.27)$ & $-0.05(0.27)$ \\
\hline Other countries & & & $\begin{array}{l}-0.03 \\
(0.21)\end{array}$ & $-0.14(0.24)$ \\
\hline Country groups & & & $\begin{array}{l}-0.10 \\
(0.27)\end{array}$ & $-0.31(0.24)$ \\
\hline \multicolumn{5}{|l|}{ Type of Study } \\
\hline Academic Study & & & Reference & Reference \\
\hline Research Report & & & $\begin{array}{l}0.42(0.16) \\
*\end{array}$ & $0.30(0.15) \#$ \\
\hline $\begin{array}{l}\text { Number of } \\
\text { Observations }\end{array}$ & 30 & 30 & 30 & 30 \\
\hline R-Squared & 0.09 & 0.40 & 0.25 & 0.55 \\
\hline
\end{tabular}

Robust standard errors in parentheses; ${ }^{* *} \mathrm{p}<0.01$, *p $<0.05$; $\# \mathrm{p}<0.10$.

$30 \%$ greater probability of reporting a positive net employment effect, even when controlling for methodology and included effects. Hence, the fact that the policy reports have a greater tendency to report positive net employment effects cannot be attributed only to their more intensive use of analytical versus CGE and I/O methods or the non-inclusion of induced effects but also to other (unexplored) factors. These unexplored factors include the fact that there is a positive reporting bias to support further development of the CE. This finding is of importance, as policy makers, organizations and institutions develop policy based on the results of these reports. By realizing that there is a potential bias in the estimation of the reported net employment effects, policymakers need to consider different or additional information to make better strategic decisions.

\section{Conclusion and policy implications}

Over the past few years, numerous studies have examined the net employment effects of renewable energy. Although the majority of them conclude that the net employment effects will be positive, some studies are less optimistic about net employment creation, and the outcomes seem to depend very much on the methodology. The estimations that include induced effects are generally less optimistic about net employment creation in the wake of the energy transition. Partly because policy reports tend to use methodologies that do not include induced effects, they generally report more positively about net employment creation related to renewable energy than do academic studies. Where the direct and indirect employment effects are generally positive, the induced effects can be either positive or negative (Mu et al., 2018). Specifically, the disappearance of conventional energy sources and competition for capital are expected to decrease net employment, while the effects of changes in electricity prices, labour wages and household income are uncertain.

As only a limited number of studies include induced effects, the current literature is perhaps too enthusiastic about the net employment effects of renewable energy and energy efficiency, and future studies and policy reports need to take into account the induced effects (for an early warning, see also Lesser, 2010). This is also important when examining other parts of the $\mathrm{CE}$, such as recycling and the sharing economy. Currently, the literature has not considered all of these aspects, but such an analysis is very much needed to inform the public and policymakers about the consequences of making the economy more circular. At the same time, our study shows that policymakers have to be cautious when drawing conclusions regarding net employment creation based on a single study. Deception is possible since the presented results may be sensitive to model specification, and studies may not consider all potential effects of a transition. More attention to the particularities of the studies is therefore also warranted in the policy arena.

\section{Acknowledgements}

This work was supported by the Goldschmeding Foundation for People, Work and Economy. All errors remain the authors'.

\section{References}

UNEP, 2008. Green jobs: towards decent work in a sustainable, low-carbon world, New solutions: a journal of environmental and occupational health policy : NS. .

Bach, S., Kohlhaas, M., Meyer, B., Praetorius, B., Welsch, H., 2002. The effects of environmental fiscal reform in Germany: a simulation study. Energy Policy 30, 803-811. https://doi.org/10.1016/S0301-4215(02)00005-8.

Bailie, A., Bernow, S., Dougherty, W., Lazarus, M., K, S., 2001. Clean Energy: Jobs for America's Future.

Barrett, J.P., Hoerner, J.A., Bernow, S., Dougherty, B., 2002. CLEAN ENERGY and JOBS: A Comprehensive Approach to Climate Change and Energy Policy.

Bezdek, R.H., Wendling, R.M., 2005. Potential long-term impacts of changes in US vehicle fuel efficiency standards. Energy Policy 33, 407-419. https://doi.org/ 10.1016/j.enpol.2003.08.015.

Blazejczak, J., Braun, F.G., Edler, D., Schill, W.P., 2014. Economic effects of renewable energy expansion: a model-based analysis for Germany. Renew. Sustain. Energy Rev. 40, 1070-1080. https://doi.org/10.1016/j.rser.2014.07.134.

Blyth, W., Gross, R., Speirs, J., Sorrell, S., Nicholls, J., Dorgan, A., Hughes, N., 2014. Low Carbon Jobs: the Evidence for Net Job Creation from Policy Support for Energy Efficiency and Renewable Energy.

Böhringer, C., Keller, A., van der Werf, E., 2013. Are green hopes too rosy? Employment and welfare impacts of renewable energy promotion. Energy Econ. 36, 277-285. https://doi.org/10.1016/j.eneco.2012.08.029. 
Bouzaher, A., Sahin, S., Yeldan, E., 2015. HOW to go green: a general equilibrium investigation of environmental policies for sustained growth with an application to Turkey???s economy. Lett. Spat. Resour. Sci. 8, 49-76. https://doi.org/10.1007/ s12076-014-0124-0.

Burger, M., Stavropoulos, S., Ramkumar, S., Dufourmont, J., van Oort, F., 2019. The heterogeneous skill-base of circular economy employment. Res. Policy. https://doi. org/10.1016/j.respol.2018.08.015.

Cai, W., Wang, C., Chen, J., Wang, S., 2011. Green economy and green jobs: myth or reality? The case of China's power generation sector. Energy 36, 5994-6003. https://doi.org/10.1016/j.energy.2011.08.016.

Cambridge Econometrics, 2014. Study on Modelling of the Economic and Environmental Impacts of Raw Material Consumption.

Cambridge Econometrics Trinomics, ICF, 2018. Impacts of Circular Economy Policies on the Labour Market (Brussels).

Caudill, S.B., 1988. Practitioners corner: an advantage of the linear probability model over probit or logit. Oxf. Bull. Econ. Stat. https://doi.org/10.1111/j.1468 0084.1988.mp50004005.x.

Chateau, J., Saint-Martin, A., 2013. Economic and employment impacts of climate change mitigation policies in OECD: a general-equilibrium perspective. Int. Econ. 135-136, 79-103. https://doi.org/10.1016/j.inteco.2013.08.001.

Clean Energy Jobs and Investment in Regional Australia, 2009. (Australia).

Ellabban, O., Abu-Rub, H., Blaabjerg, F., 2014. Renewable energy resources: current status, future prospects and their enabling technology. Renew. Sustain. Energy Rev. https://doi.org/10.1016/j.rser.2014.07.113.

Frey, C.B., Osborne, M.A., 2017. The future of employment: how susceptible are jobs to computerisation? Technol. Forecast. Soc. Chang. https://doi.org/10.1016/j. techfore.2016.08.019.

Garrett-Peltier, H., 2017. Green versus brown: comparing the employment impacts of energy efficiency, renewable energy, and fossil fuels using an input-output model. Econ. Modell. 61, 439-447. https://doi.org/10.1016/j.econmod.2016.11.012.

Heindl, P., Voigt, S., 2012. Employment effects of regional climate policy: the case of renewable energy promotion by feed-in tariffs. SSRN Electron. J. https://doi.org/ $10.2139 /$ ssrn. 2159191.

Henriques, C.O., Coelho, D.H., Cassidy, N.L., 2016. Employment impact assessment of renewable energy targets for electricity generation by 2020 - an IO LCA approach. Sustain. Cities Soc. 26, 519-530. https://doi.org/10.1016/j.scs.2016.05.013.

Hergovich, S., Paprsek, M., 2015. Tapping the job potential of green investments in Europe. In: Galgóczi, B. (Ed.), Europe’s Energy Transformation in the Austerity Trap. ETUI, Brussels.

Hillebrand, B., Buttermann, H.G., Behringer, J.M., Bleuel, M., 2006. The expansion of renewable energies and employment effects in Germany. Energy Policy 34, 3484-3494. https://doi.org/10.1016/j.enpol.2005.06.017.

Johnson, T.P., 2014. Snowball sampling: introduction. In: Wiley StatsRef: Statistics Reference Online.

Kammen, D.M., Kapadia, K., Fripp, M., 2004. Putting renewables to work: how many jobs can the clean energy industry generate? Energy 1-28. https://doi.org/10.1080/ $09603100701222309,2004$.

Kirchherr, J., Reike, D., Hekkert, M., 2017. Conceptualizing the circular economy: an analysis of 114 definitions. Resour. Conserv. Recycl. 127, 221-232. https://doi.org/ 10.1016/j.resconrec.2017.09.005.

Lacy, P., Rutqvist, J., 2016. Waste to Wealth: the Circular Economy Advantage, Waste to Wealth: the Circular Economy Advantage.

Lambert, R.J., Silva, P.P., 2012. The challenges of determining the employment effects of renewable energy. Renew. Sustain. Energy Rev. 16 (7), 4667-4674. https://doi.org/ 10.1016/j.rser.2012.03.072.

Lehr, U., Lutz, C., Edler, D., 2012. Green jobs? Economic impacts of renewable energy in Germany. Energy Policy 47, 358-364. https://doi.org/10.1016/j. enpol.2012.04.076.

Lesser, J.A., 2010. Renewable energy and the fallacy of 'green'jobs. Electr. J. 23 (7), 45-53. https://doi.org/10.1016/j.tej.2010.06.019.
Lovins, A., Michael, B., 2014. A New Dynamic - Effective Business in a Circular Economy, the Business Angle of a Circular Economy - Higher Competitiveness, Higher Resource Security and Material Efficiency.

Lund, H., Hvelplund, F., 2012. The economic crisis and sustainable development: the design of job creation strategies by use of concrete institutional economics. Energy 43, 192-200. https://doi.org/10.1016/j.energy.2012.02.075.

Maia, J., Giordano, T., Kelder, N., Bardien, G., Bodibe, M., du Plooy, P., Jafta, X.J.D., Kruger-Cloete, E., Kuhn, G., Lepelle, R., Makaulule, L., Mosoma, K., Neoh, S. Netshitomboni, N., Ngozo, T., Swanepoel, J., 2011. Green Jobs: an Estimate of the Direct Employment Potential of a Greening South African Economy. Midrand and Pretoria, Johannesburg.

Markandya, A., Arto, I., González-Eguino, M., Román, M.V., 2016. Towards a green energy economy? Tracking the employment effects of low-carbon technologies in the European Union. Appl. Energy 179, 1342-1350. https://doi.org/10.1016/j. apenergy.2016.02.122.

Meyer, I., Sommer, M.W., 2014. Employment Effects of Renewable Energy Supply A Meta Analysis Employment Effects of Renewable Energy Supply-A Meta Analysis $1-2$

Moreno, B., López, A.J., 2008. The effect of renewable energy on employment. The case of Asturias (Spain). Renew. Sustain. Energy Rev. 12, 732-751. https://doi.org/ 10.1016/j.rser.2006.10.011.

Morgan, J., Mitchell, P., 2015. Opportunities to Tackle Britain's Labour Market Challenges through Growth in the Circular Economy.

Morgan, J., Mitchell, P., 2015. Employment and the Circular Economy. Job Creation in a More Resource Efficient Britain, vol. 28.

Moscovitch, E., 1994. DSM in the broader economy: the economic impacts of utility efficiency programs. Electr. J. 7, 14-28. https://doi.org/10.1016/1040-6190(94) 90138-4.

Mu, Y., Cai, W., Evans, S., Wang, C., Roland-Holst, D., 2018. Employment impacts of renewable energy policies in China: a decomposition analysis based on a CGE modeling framework. Appl. Energy 210, 256-267. https://doi.org/10.1016/j. apenergy.2017.10.086.

Neuwahl, F., Löschel, A., Mongelli, I., Delgado, L., 2008. Employment impacts of EU biofuels policy: combining bottom-up technology information and sectoral market simulations in an input-output framework. Ecol. Econ. 68, 447-460. https://doi.org/ 10.1016/j.ecolecon.2008.04.018.

Pollin, R., Heintz, J., Garrett-peltier, H., 2009. The Economic Benefits of Investing in Clean Energy. How the economic stimulus program and new legislation can boost U. S. economic growth and employment. Dep. Econ. Polit. Econ. Res. Inst.

Schut, E., Crielaard, M., Mesman, M., 2016. Circular Economy in the Dutch Construction Sector: A Perspective for the Market and Government.

Scott, M.J., Roop, J.M., Schultz, R.W., Anderson, D.M., Cort, K.A., 2008. The impact of DOE building technology energy efficiency programs on U.S. employment, income, and investment. Energy Econ. 30, 2283-2301. https://doi.org/10.1016/j. eneco.2007.09.001.

Staiß, F., Kratzat, M., Nitsch, J., Lehr, U., Edler, D., Lutz, C., 2006. Erneuerbare Energien: Arbeitsplatzeffekte-Wirkungen des Ausbaus erneuerbarer Energien auf den deutschen Arbeitsmarkt. BMU, Berlin, Germany.

Tanner-Smith, E.E., Tipton, E., 2014. Robust variance estimation with dependent effect sizes: practical considerations including a software tutorial in Stata and SPSS. Res. Synth. Methods. https://doi.org/10.1002/jrsm.1091.

Van Oort, F.G., Ramkumar, S., Stavropoulos, S., Burger, M.J., Dufourmont, J., Thissen, M., 2018. Putting the Circular Economy to Work: Measuring Gross Employment Effects in the Netherlands, pp. 1996-2015.

Wei, M., Patadia, S., Kammen, D.M., 2010. Putting renewables and energy efficiency to work: how many jobs can the clean energy industry generate in the US? Energy Policy 38, 919-931. https://doi.org/10.1016/j.enpol.2009.10.044.

Whiteley, M., Zervos, A., 1999. Meeting the Targets and Putting Renewables to Work.

Ziegelmann, A., Mohr, M., Unger, H., 2000. Net employment effects of an extension of renewable-energy systems in the Federal Republic of Germany. Appl. Energy 65, 329-338, https://doi.org/10.1016/S0306-2619(99)00072-0. 